\title{
Dynamics of Quantitative Variation for Escherichia coli in Meat Industry Wastewaters
}

\author{
Krzysztof BERLEĆ, Katarzyna BudZiŃSKA, Anita JUREK and Magdalena MiCHALSKA
}

Accepted November 4, 2005

\begin{abstract}
BERLEĆ K., BUDZIŃSKA K., JUREK A., MiChALSKA M. 2005. Dynamics of quantitative variation for Escherichia coli in meat industry wastewaters. Folia biol. (Kraków) 53 (Suppl.): 151-156.

The experiment consisted of determining the number of $E$. coli in raw wastewater from meat industry and establishing the elimination rate for this species at temperatures: 4, 20, 30 and $40^{\circ} \mathrm{C}$. The highest amount of $E$. coli was observed in the autumn $\left(2.5 \times 10^{9} \mathrm{cfu} / \mathrm{ml}\right)$. E. coli elimination was fastest at $40^{\circ} \mathrm{C}$, at $20^{\circ} \mathrm{C}$ it was the slowest. The temperature of $40^{\circ} \mathrm{C}$ reduced E. coli completely within 8 days.
\end{abstract}

Key words: Survival, Escherichia coli, sludge, wastewaters

Krzysztof BERLEĆ. Department of Animal Hygiene and Microbiological Environment, University of Technology and Agriculture, Mazowiecka 28, 85-084 Bydgoszcz, Poland. E-mail:kberlec@wp.pl

Wastewaters from the meat industry are a potential source of epidemic risk, owing to considerable amounts of chyme (the content of stomachs and intestines) and blood from beef animals. These wastes get into wastewater and further into the environment, causing a sanitary-epidemic threat. Pathogenic viruses, fungi, bacteria and parasites, which can be found in wastewaters from the meat industry, are an epidemic hazard for people and animals. Therefore, effective methods of their utilization have been sought for many years. The methods used so far are too energy-consuming and material intensive (GERBA \& BITTON 1984).

Meat industry wastewaters are formed in slaughter houses and meat processing factories, among others, as a result of slaughter, carcass partitioning and intestine dressing. In processing plants, the main part of the sewage originates from washing and disinfection of appliances used in the processing procedures. The quantities and qualities of wastewater and sludge depend on both the health state of slaughtered animals and the water consumption for the hygiene of processing appliances.

In sludge from meat industry, pathogenic viruses, bacteria, parasite eggs and oocysts e.g. tapeworms, roundworms, coccidia, and many others, are a hazard for health. The following bacteria should be particularly paid attention to: Salmonella, Clostridium, Bacillus, Brucella, Shigiella; viruses such as Aujeszk's disease, foot and mouth disease, pig plague, and many others. In case there are no sanitary procedures or sludge is not used in agriculture, microbes and parasite eggs may spread in water and soil.

A variety of microbes in sewage sludge are one of the most important obstacles considerably limiting the use of sewage sludge for land reclamation. Meat industrial sewage sludge may become a primary or additional source of pathogenic flora, leading to environment and ground water contamination in the places of their discharge, which produces a serious hazard. Using sludge in agriculture, one should take into account that these organisms are able to live in soil or on plants for weeks, months and even years.

As far as environment protection is concerned, wastewater treatment processes applied to the meat industry are often ineffective. So, new solutions characterized by high effectiveness of wastewater treatment are being sought.

\section{Material and Methods}

The aim of the research was to assess the existence of Escherichia coli in wastewaters from meat industry and its survival rate at temperatures of $4,20,30$ and $40^{\circ} \mathrm{C}$.

The subject of the research included raw wastewaters from meat processing plants. The wastewater samples of volume $1000 \mathrm{ml}$ were taken 7 times 
during each of the testing periods, i.e. in spring, summer and autumn.

Quantitative germ determination was based on the calculation of the most probable number (MPN) with the use of McCrady tables. To determine the number of E. coli by using the MPN method, samples of wastewater in three replications were placed on a liquid medium, which was MacConkey broth (Merck, Art. No. 105396), by preparing dilution orders from $10^{-1}$ up to $10^{-10} .1 \mathrm{ml}$ of the tested wastewater was introduced into each tube with $9 \mathrm{ml}$ of the liquid medium-MacConkey broth. Then the samples with the implanted broth were incubated for $24-48 \mathrm{~h}$ at $37^{\circ} \mathrm{C}$. After incubation, in order to confirm identification of both positive and doubtful samples, an inoculation with an aseptic oese was made on a selective solid medium Tergitol-7-agar (Merck, Art. Nr 5471). The media were incubated at $37^{\circ} \mathrm{C}$ for $24 \mathrm{~h}$.

The estimation consisted of stating color change of the individual testing broths from violet into yellow and the presence of gas in the tested tube. On the tested solid medium, Escherichia coli bacteria grew in a form of yellow colonies around which a medium color change from green into yellow was observed.

To make a suspension for testing survival rate of bacteria at given temperatures, $500 \mathrm{ml}$ of nutrient broth was made acc. to Standard I - Nahrbouillon; Art. No 7882. The suspension was inoculated by a bacterial colony of Escherichia coli (EHEC strain) with the use of an aseptic oese. In a glass vessel of vol. $2000 \mathrm{ml}$, a mixture of $1000 \mathrm{ml}$ of the tested wastewater and $400 \mathrm{ml}$ of the suspension was prepared and then incubated at $37^{\circ} \mathrm{C}$ for $24 \mathrm{~h}$. Next, the obtained suspension was poured into four flasks, $450 \mathrm{ml}$ each. The flasks were incubated at
Table 1

The total number of $E$. coli in wastewaters in individual testing periods

\begin{tabular}{|c|c|c|c||}
\hline \multirow{2}{*}{$\begin{array}{c}\text { Number of } \\
\text { sample }\end{array}$} & \multicolumn{3}{|c||}{ Number of E. coli $(\mathrm{cfu} / \mathrm{ml})$} \\
\cline { 2 - 4 } & Spring & Summer & Autumn \\
\hline \hline 1. & $9.5 \times 10^{6}$ & $2.0 \times 10^{4}$ & $2.0 \times 10^{6}$ \\
\hline 2. & $9.5 \times 10^{5}$ & $2.5 \times 10^{5}$ & $2.5 \times 10^{9}$ \\
\hline 3. & $9.5 \times 10^{1}$ & n.s. & $2.5 \times 10^{2}$ \\
\hline 4. & $9.5 \times 10^{2}$ & $1.5 \times 10^{3}$ & $2.5 \times 10^{2}$ \\
\hline 5. & $3.0 \times 10^{3}$ & $9.5 \times 10^{2}$ & $0.9 \times 10^{1}$ \\
\hline 6. & $4.5 \times 10^{3}$ & $2.0 \times 10^{4}$ & n.d. \\
\hline 7. & $0.4 \times 10^{1}$ & $0.7 \times 10^{1}$ & n.d. \\
\hline
\end{tabular}

n.d. - not detected

Table 2

Survival rate of $E$. coli in wastewaters from the meat industry

\begin{tabular}{||c|c|c|c|c||}
\hline \multirow{2}{*}{$\begin{array}{c}\text { Number } \\
\text { of } \\
\text { sample }\end{array}$} & \multicolumn{3}{|c||}{ Number of E. coli $(\mathrm{cfu} / \mathrm{ml})$} \\
\cline { 2 - 5 } & $4^{\circ} \mathrm{C}$ & $20^{\circ} \mathrm{C}$ & $30^{\circ} \mathrm{C}$ & $40^{\circ} \mathrm{C}$ \\
\hline \hline I. & $9.5 \times 10^{9}$ & $2.5 \times 10^{12}$ & $2.0 \times 10^{11}$ & $4.5 \times 10^{10}$ \\
\hline II. & $2.5 \times 10^{9}$ & $2.5 \times 10^{11}$ & $9.5 \times 10^{9}$ & $9.5 \times 10^{12}$ \\
\hline III. & $4.5 \times 10^{9}$ & $4.5 \times 10^{10}$ & $2.5 \times 10^{9}$ & $2.5 \times 10^{7}$ \\
\hline IV. & $2.5 \times 10^{9}$ & $1.5 \times 10^{10}$ & $2.5 \times 10^{8}$ & $9.5 \times 10^{5}$ \\
\hline V. & $4.5 \times 10^{8}$ & $2.5 \times 10^{9}$ & $2.5 \times 10^{7}$ & $4.5 \times 10^{4}$ \\
\hline VI. & $2.5 \times 10^{7}$ & $2.5 \times 10^{9}$ & $9.5 \times 10^{5}$ & $2.5 \times 10^{1}$ \\
\hline VII. & $2.5 \times 10^{6}$ & $2.5 \times 10^{8}$ & $4.5 \times 10^{3}$ & $2.5 \times 10^{1}$ \\
\hline VIII. & $2.5 \times 10^{5}$ & $2.5 \times 10^{7}$ & $4.5 \times 10^{3}$ & 0.0 \\
\hline
\end{tabular}

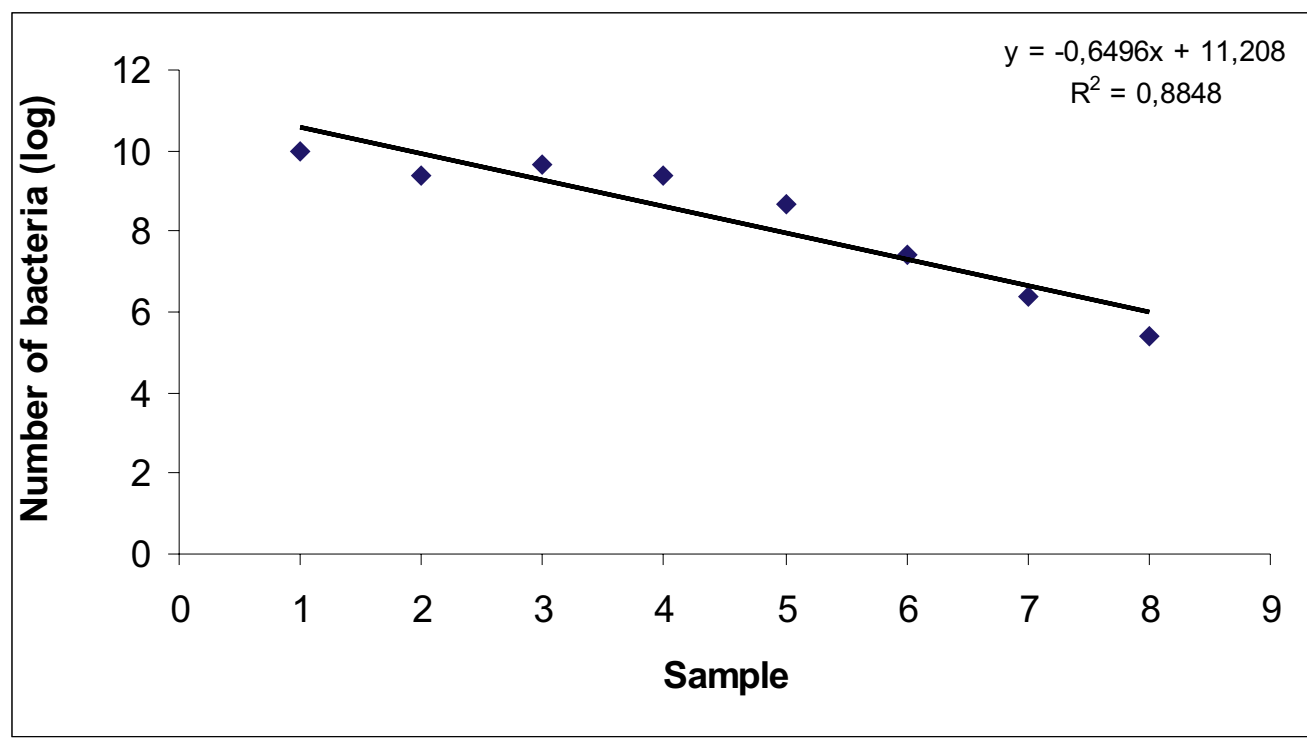

Fig. 1. Regression line showing the decrease in the number of E. coli at $4^{\circ} \mathrm{C}$. 


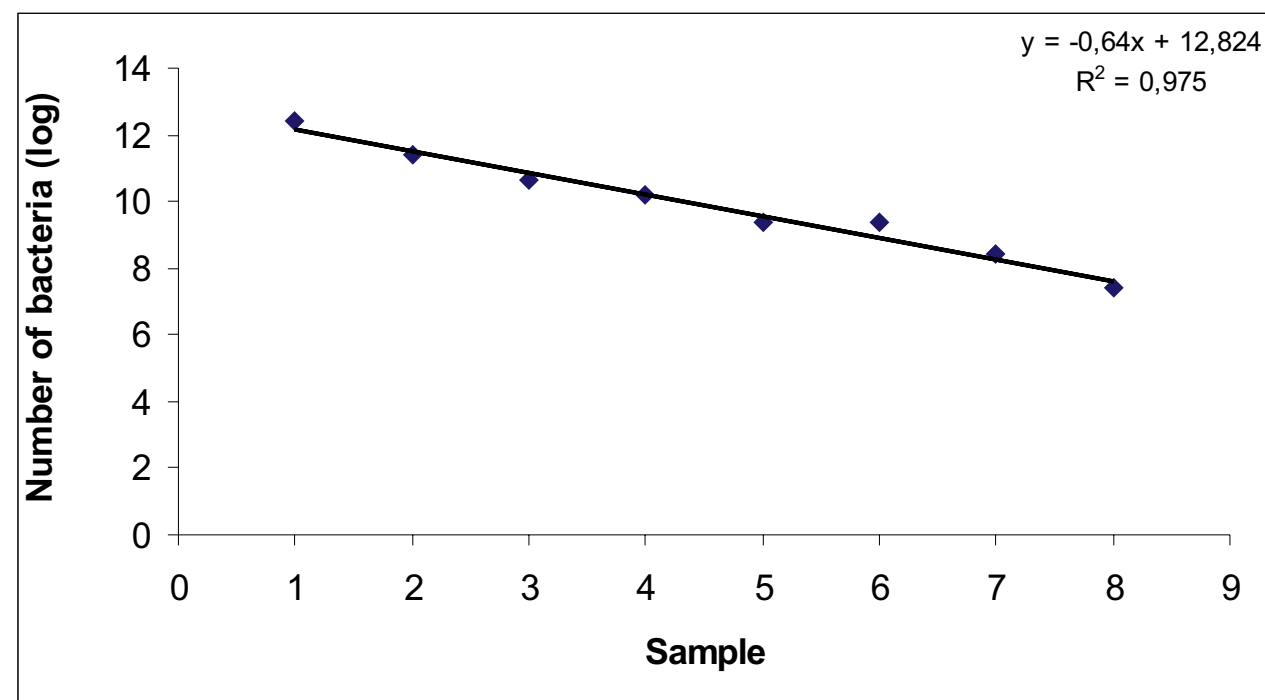

Fig. 2. Regression line showing the decrease in the number of E. coli at $20^{\circ} \mathrm{C}$.

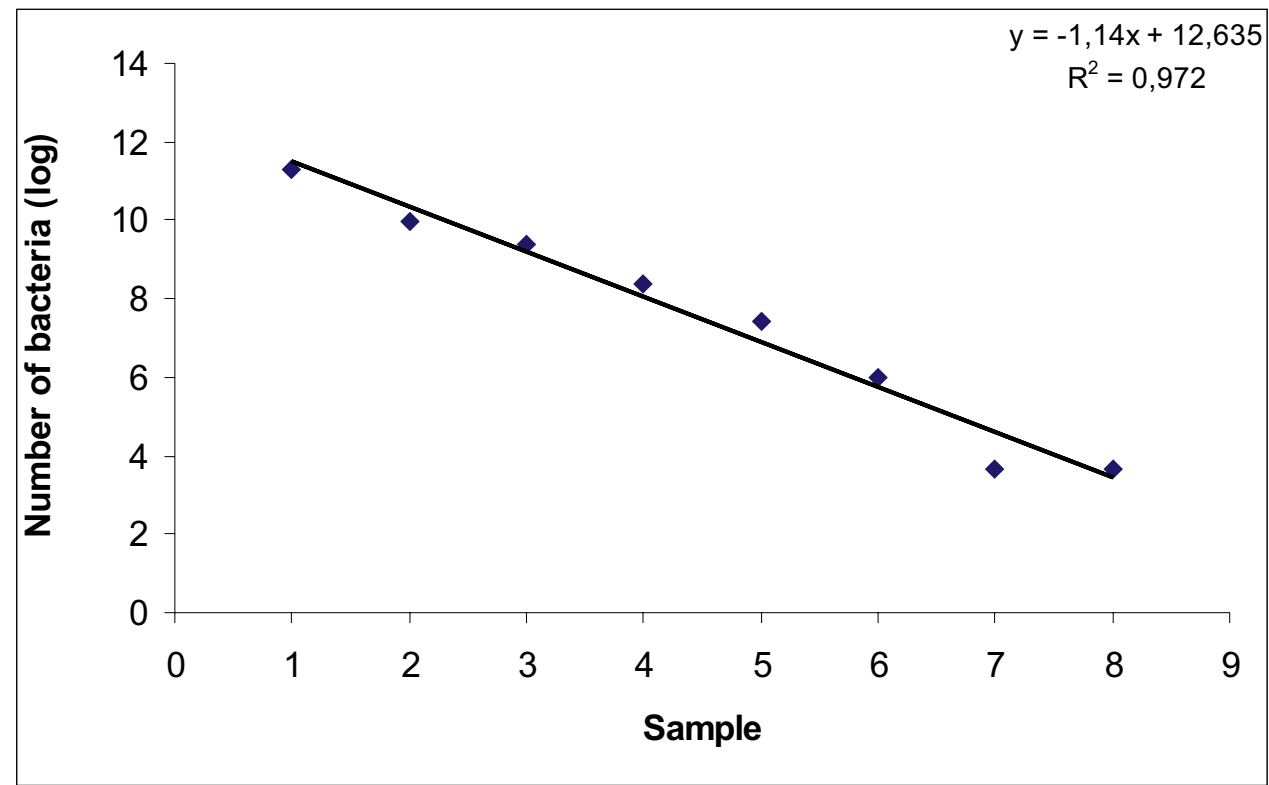

Fig. 3. Regression line showing the decrease in the number of E. coli at $30^{\circ} \mathrm{C}$.

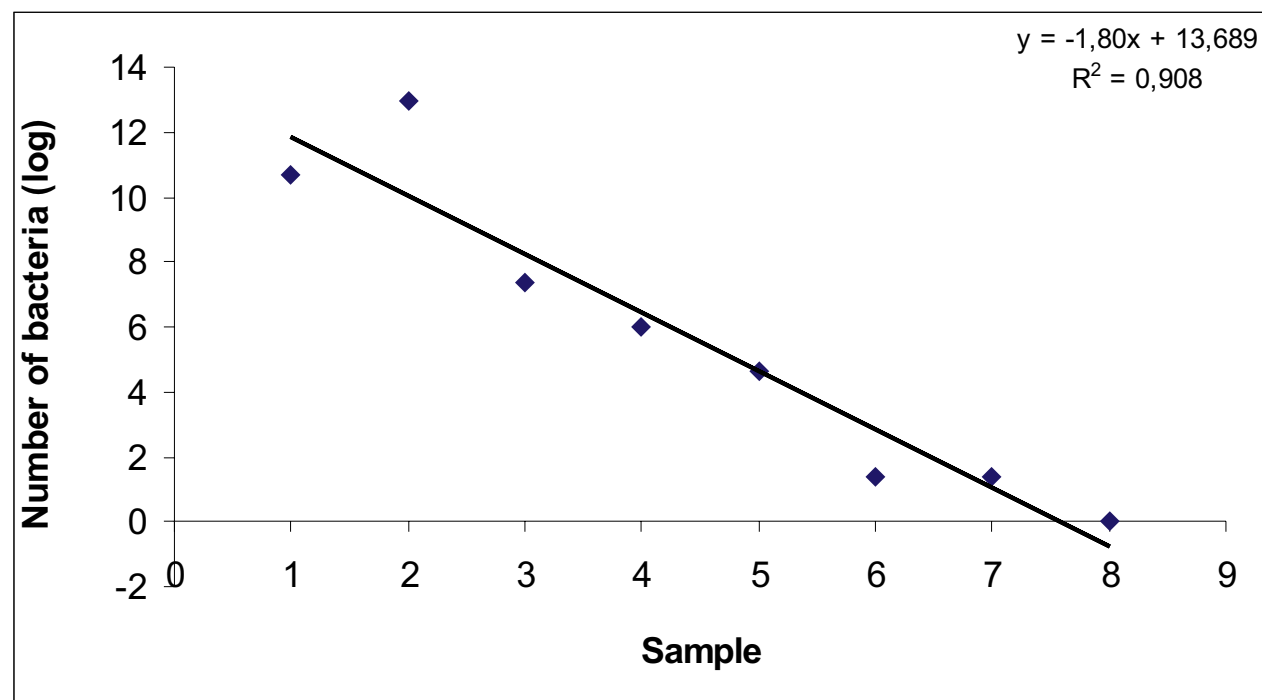

Fig. 4. Regression line showing the decrease in the number of E. coli at $40^{\circ} \mathrm{C}$. 
required temperatures, determining the number of E. coli: for temperatures 4 and $20^{\circ} \mathrm{C}$ - every two days, and for temperatures 30 and $40^{\circ} \mathrm{C}$ - every day. The individual stages determining the number of microbes ran in the same way as $E$. coli were determined in the wastewater taken for testing. In the wastewater taken for testing survival rates, Escherichia coli was not found.

\section{Results and Discusion}

The results of tests for both the presence and survival rate of $E$. coli in wastewater are presented in Tables 1 and 2 and in Figures 1-4.

In the raw wastewater, many groups of microorganisms occurring in natural conditions can be found, such as bacteria, viruses, bacteriophages, yeast-like fungi and molds, and parasites. Apart from sewage germ forms, there are also species living mostly in soil, air, in animal and human digestive tracks, and others. The occurrence in wastewaters of pathogenic microorganisms poses a serious epidemiologic and bacteriologic problem.

This study concerning Escherichia coli in wastewaters from the meat industry was conducted in three periods: spring, summer and autumn. The highest number of bacteria $\left(2.5 \times 10^{9} \mathrm{cfu} / \mathrm{ml}\right)$ was observed in autumn. No bacteria were observed twice in autumn and once in spring (Table 1).

MICHALSKA and BUDZIŃSKA (2001) estimated raw and treated wastewaters in a bacteriological aspect. In their opinion, the amount of bacteria in raw wastewater is dependent on the supplied raw material, but the survival rate is affected by many factors, such as reaction, temperature, oxygen concentrations, and the amount of the organic substance or the number of species living in the tested wastewater. The studies proved that the number of bacteria from the family Enterobacteriaceae in raw wastewaters ranged from $2.2 \times 10^{7} \mathrm{cfu} / \mathrm{ml}$ in July up to $6.5 \times 10^{8} \mathrm{cfu} / \mathrm{ml}$ in December. The process of fermentation reduced their amount by three orders of magnitude $\left(7.0 \times 10^{5} \mathrm{cfu} / \mathrm{ml}\right)$. The number of the tested microorganisms in the treated wastewater definitely decreased and was on average $7.1 \times 10^{3} \mathrm{cfu} / \mathrm{ml}$ with the highest concentration found in February $\left(2.2 \times 10^{4} \mathrm{cfu} / \mathrm{ml}\right)$ and the lowest - in summer months $\left(10^{2} \mathrm{cfu} / \mathrm{ml}\right)$. KLUCZEK and HERMAN (1995) noted that the family Enterobacteriaceae is characterized by small nutrient requirements and their adaptability to damp environments with traced amounts of carbon and nitrogen compounds is also insignificant. These organisms are able to create forms resistant to the most toxic agents against them (e.g. antibiotics or disinfectants). They become dangerous for humans and animals when disorders in the biocenotic balance or in human or animal immunity take place.

The analyses showed that the tested wastewater contained bacteria of higher or lower epidemic significance. Despite the occurrence of such bacteria as Proteus vulgaris, Escherichia coli, Straphylococcus areus, it can be assumed that they cannot be a threat, owing to quite a significant reduction in the total number of micoroorganisms in the treated eluents.

The analysis of wastewaters from meat processing plants made by BUDZIŃSKA and JUREK (2003) confirms that some percentage of people and animals suffer different types of infections. In wastewaters after mechanical treatment, the total number of bacteria from the family Enterobacteriaceae including $E$. coli ranged from $5.81 \times 10^{5} \mathrm{cfu} / \mathrm{ml}$ to $1.49 \times 10^{7} \mathrm{cfu} / \mathrm{ml}$. The highest number of bacteria was observed in June $1.49 \times 10^{7} \mathrm{cfu} / \mathrm{ml}$ and the lowest - in September $5.81 \times 10^{5} \mathrm{cfu} / \mathrm{ml}$. The number of bacteria of the family Enterobacteriaceae in wastewaters after chemical treatment ranged from $1.65 \times 10^{5} \mathrm{cfu} / \mathrm{ml}$ to $7.68 \times 10^{6} \mathrm{cfu} / \mathrm{ml}$. June was the month when the highest bacteria number was noticed $-7.68 \times 10^{6} \mathrm{cfu} / \mathrm{ml}$, but the lowest number of organisms was stated in July $-1.65 \times 10^{5} \mathrm{cfu} / \mathrm{ml}$. During the experiment the number of bacteria of the family Enterobacteriaceae in biologically treated wastewaters ranged from $1.61 \times 10^{4} \mathrm{cfu} / \mathrm{ml}$ to $8.41 \times 10^{5} \mathrm{cfu} / \mathrm{ml}$. The highest number of bacteria was observed in June: $8.41 \times 10^{5} \mathrm{cfu} / \mathrm{ml}$ and the lowest one - in July: $1.61 \times 10^{4} \mathrm{cfu} / \mathrm{ml}$.

The occurrence of the individual microbes in sludge reflects the microbiological condition of wastewaters. Owing to the dewatering ratio and, consequently, changes in the other parameters, some differences may be observable among different biotopes. BUDZIŃSKA (2000) found a considerable contamination of sludge with colibacillus. Their largest amount was found in meat sediments/sludge $(7.5 \times 10 \mathrm{cfu} / \mathrm{g})$, a little smaller - in communal sludge $\left(9.5 \times 10^{6} \mathrm{cfu} / \mathrm{g}\right)$, and the lowest in sediments/sludge from fruit and vegetable processing industry.

BUDZIŃSKA et al. (2001) claim that sludge is easily putrescible and makes a good medium for breeding microorganisms. Depending on different contents of the sludge, these processes can run more or less intensively. Similar results were obtained by OLSZEWSKA et al. (2001), who determined the number of colibacillus in sludge after digestion at $2.1 \times 10^{7} \mathrm{cfu} / \mathrm{g}$. The research also showed that the lowest concentration was stated in January $\left(4.0 \times 10^{4} \mathrm{cfu} / \mathrm{g}\right)$, but the highest- in October, December, February and March $\left(4.5 \times 10^{7} \mathrm{cfu} / \mathrm{g}\right.$ of the tested sludge). A similar number of colibacillus was separated (on average $2.7 \times 10^{7} \mathrm{cfu} / \mathrm{g}$ ) in a sludge flotate. While conducting the research, the coli ti- 
tre ranged from $10^{-5}$ to $10^{-7}$, exceeding Polish permissible standard $\left(10^{-3}\right)$ (OLSZEWSKA et al. 2001).

In this study, putrescibility of Escherichia coli showed that their number decreased fastest at $40^{\circ} \mathrm{C}$. At this temperature, the microorganisms decayed after eight days of testing (Fig. 1). A temperature of $30^{\circ} \mathrm{C}$ also proved to produce fast decay of the bacteria $E$. coli in wastewaters from the meat industry - on the eighth day of the test their number decreased to $4.5 \times 10^{3} \mathrm{cfu} / \mathrm{ml}$ (Fig. 2). $E$. coli were eliminated longest but stably at $20^{\circ} \mathrm{C}$ $\left(2.5 \times 10^{7} \mathrm{cfu} / \mathrm{ml}\right)-$ during 15 days of the test the bacteria number decreased only by five orders of magnitude (Fig. 3). For $4^{\circ} \mathrm{C}$, the elimination was much faster than at $20^{\circ} \mathrm{C}$. From the seventh day of the test and at a temperature of $4^{\circ} \mathrm{C}$, the bacteria started to reduce systematically to achieve a final result of $2.5 \times 10^{5} \mathrm{cfu} / \mathrm{ml}$ on the 15 th day of the test (Fig. 4). The elimination rate of E. coli is not the same at all temperatures. At each temperature the reduction takes its individual way: the higher the temperature, the shorter the survival time of the tested bacteria (Table 2).

Colibacillus is of low resistance to detrimental factors of its outer environment. It decays generally at $60^{\circ} \mathrm{C}$ after $20 \mathrm{~min}$. Some of its strains in milk can outlast pasteurization at $62.8^{\circ} \mathrm{C}$. In cool or tepid water containing nutrients, colibacillus is able survive for moths. In excrement at $0^{\circ} \mathrm{C}$, you can prove its presence even after a year (SORBER \& MOORE 1987). BUDZIŃSKA et al. (2001) has shown that $E$. coli found in sewage is reduced fastest at $28^{\circ} \mathrm{C}$, however, KLUCZEK \& HERMAN (1995) maintain that, depending on the conditions of the experiment, bacterial survival time in liquid manure ranges from 3 to 36 months.

BUDZIŃSKA et al. (2001) have undertaken the research with the aim of analyzing the behavior of the indicatory bacteria in sludge from selected meat processing wastewater treatment plants. $E$. coli, Enterococcus faecalis and Salmonella rods were used as indicatory bacteria, being commonly applied to determine the contamination of fecal origin. The sludge samples introduced into compost piles contained $E$. coli rods in the amount of $4.5 \times 10^{8}$ cells per $1 \mathrm{~g}$, etnerococcuses $-4.0 \times 10^{8}$ units $/ \mathrm{g}$ and Salmonella spp. $-4.0 \times 10^{7} \mathrm{cfu} / \mathrm{g}$. The tests determined the number of fecal bacteria in the individual samples of raw sludge, and the survival time for $E$. coli was defined in the sludge stored in compost piles.

Sludge is not a normal habitat for intestinal bacteria, so they are eliminated spontaneously after some time. The analysis of the obtained results made by BUDZIŃSKA et al. (2001) shows that the survival rates of the tested bacteria were significantly different, depending on species. Enterococ- cus (Streptococcus fecalis), compared to E. coli and Salmonella spp., was characterized by the highest ability to adapt to the environment of sludge, shown by their longest time of survival.

BUDZIŃSKA (2000) showed a distinct decayability of $E$. coli cells: in the sixth month of storage, in the material from a municipal treatment plant, $1.5 \times 10^{1}$ of $E$. coli colonies were found; however, the next stages of the experiment showed no colibacillus. The material from a fruit and vegetable industrial wastewater treatment plant, owing to its specificity and particularly because of its large acidity, did not make a good environment for the development of $E$. coli. The decay rate of those cells was highest and in the sixth month of study $E$. coli was not isolated. The differences in the survival time of $E$. coli might result from a specificity of physico-chemical contents of the tested materials, an initial abundance of these bacteria in the individual raw sludge, and also from other not recognized environmental factors.

Sludge storage contributes to a decrease in fecal bacteria, which, with time, finally undergo total reduction.

In PALUSZAK's experiment (1998), enterococcus was observed up to 28 weeks after fertilization with liquid manure. Typically, 2-3 months are enough to reduce the number of pathogens to a level which is not significant sanitarily. SORBER and MOORE (1987) claim that a fast reduction in microorganism number takes place just after their introduction into soil, and the fecal bacteria number decreases 10 times within a month. PALUSZAK (2000) states that temperatures of $50.4-51.5^{\circ} \mathrm{C}$ with $\mathrm{pH}=7.67-7.78$ resulted in the elimination of EHEC microorganisms added to the liquid manure in a concentration of $1.9 \times 10^{8} / \mathrm{g}$ already after $150 \mathrm{~min}$.

A longer survival rate of bacteria has been found at low temperatures. The pathogen decay rate for temperatures from 5 to $30^{\circ} \mathrm{C}$ increases twice with a $10^{\circ} \mathrm{C}$ rise of temperature. Further, the variable conditions of freezing and thawing in winter always reduces the survival rate of pathogens in soils (OLSZEWSKA 2000).

PALUSZAK (1997) followed the behavior of E. coli in soil fertilized with liquid manure. The number of pathogens directly decreased to the time of their storage.

The advantageous effect of damp soil on the survival rate of bacteria has also been shown by other authors (GERBA \& BITTON 1984). With a large amount of easily accessible organic substance, a short term of fecal bacteria breeding in soil was observed, which may be extremely hazardous, considering pathogens. 
Neither soil nor sludge is a natural environment for fecal bacteria. With time, the population of $E$. coli underwent the process of continuous elimination.

Testing the survival rate of enteropathogenic Escherichia coli in soil-groundwater, NIEWOLAK and MiNDROW (2001) observed that organisms decayed faster in unsterile water incubated at $20^{\circ} \mathrm{C}$ and slower in the same water, but sterilized at $121^{\circ} / 10 \mathrm{~min}$. and incubated at $4^{\circ} \mathrm{C}$. The time required for the reduction of $90 \%$ of the bacteria ranged from 1 to 36 days, being shorter in the summer and longer in the autumn and winter.

The research shows that the occurrence of Escherichia coli in the natural environment is high. Its survival rate is also high in different conditions, which creates a threat of soil and water contamination because of bacteria found in wastewaters and liquid manure.

\section{References}

BUDZIŃSKA K. 2000. Contamination of sewage sludge with faecal bacteria. Pr. Kom. Nauk Roln. \& Biol. BTN, Bydgoszcz, 46: 95-109. (In Polish).

BUDZIŃSKA K., JUREK A. 2003. Comprehensive bacteriological analysis of sewage from meat-processing plants. Ekologia i Technika 9: 3-12. (In Polish).

BUDZIŃSKA K., BERLEĆ K., RZEPCZYK B., MICHALSKA M., SZEJNIUK B. 2001. Analysis of behavior of indicator bacte- ria in sludge from meat waste treatment plants. Zesz. Probl. Post. Nauk Roln. 477: 301-306. (In Polish).

GERBA C. P., BITTON G. 1984. Microbial pollutants: their survival and transport pattern to groundwater. (In: Groundwater Pollution Microbiology, Bitton B., Gerba C., Wiley \& Sons Inc. New York): 65-88.

KLUCZEK J. P., HeRMAN J. 1995. Agricultural applicability of bacterial biomass from the treatment plants of cellulose plants. Pr. Kom. Nauk. Roln. \& Biol. BTN, Bydgoszcz 43: 161-169. (In Polish).

MiCHALSKA M., BUDZIŃSKA K. 2001. Bacteriological evaluation of raw and treated sewage from meat processing plants. Pr. Kom. Nauk Rol. \& Biol., BTN, Bydgoszcz 49: 111-118. (In Polish).

NIEWOLAK S., MINDROW M. 2001. Survival of some indicator bacteria and enteric pathogens in tile drainage water. Natur.Sci. UWM Olsztyn 8: 73-86. (In Polish).

OLSZEWSKA H., PALUSZAK Z., TRACZYKOWSKI A. 2001. Microbiological evaluation of sewage sludge from meat processing plants, Zeszyty Problemowe Postępów Nauk Rolniczych 477: 451-457. (In Polish).

OLSZEWSKA H. 2000. Risk of microbiological soil contamination as a result of fertilization with slurry. Pr. Kom. Nauk. Roln. \& Biol. BTN, Bydgoszcz 47: 3-14. (In Polish).

PALUSZAK Z. 1997. Ecological aspects of slurry application based on the behavior of bacteria in soil. Katedra Higieny Zwierząt, SGGW, Problemy Higieny w Ekologizacji Rolnictwa, Symp., Warszawa, 185-190. (In Polish).

PALUSZAK Z. 1998. Study into the behavior and survivability of selected faecal microorganisms in soil fertilized with slurry. Rozprawy nr 85, Wyd. Uczelniane ATR Bydgoszcz. (In Polish).

PALUSZAK Z. 2000. Evaluation of biological slurry disinfection method. Pr. Kom. Nauk. Roln. \& Biol. BTN, Bydgoszcz 47: 15-21. (In Polish).

SORBER C. A., MOORE B. E. 1987. Survival and transport of pathogenes in sludge amended soil, a critical literature review. Report EPA/600/2-87/028 of Water Res. Lab., Office of Res. Develop. Cincinnati, Ohio. 